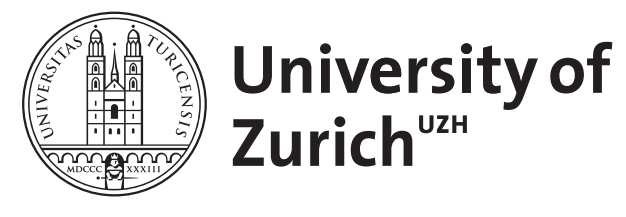

\title{
A religion of the book? On sacred texts in hinduism
}

\author{
Leach, Robert
}

\begin{abstract}
In this article I provide an overview of the identity, role and function of sacred texts in Hinduism. Hinduism's tremendous diversity extends to the numerous ways in which different types of texts have been identified as sacred and used by Hindu practitioners. It would be a mistake to attempt to summarise the role of sacred texts in the lives of Hindus, since different texts have had different roles and performed different functions. In the following, therefore, I address what I identify as the four major types or categories of sacred text in Hinduism independently of each other, while noting the commonalities they share, and some of the ways in which texts belonging to the different categories have engaged with one another. The first three of the four categories of text I address consist of Sanskrit works, and the names of the categories are Sanskrit terms which have been applied by Hindus to their own literature (Veda/Śruti; Smṛti; Tantra, Aggama and Stotra). In the final section, I depart from using "insider" terminology and address "sacred texts in vernacular languages".
\end{abstract}

DOI: https://doi.org/10.1177/0014524614537167

Posted at the Zurich Open Repository and Archive, University of Zurich ZORA URL: https://doi.org/10.5167/uzh-103719

Journal Article

Originally published at:

Leach, Robert (2014). A religion of the book? On sacred texts in hinduism. Expository Times, 126(1):1527.

DOI: https://doi.org/10.1177/0014524614537167 


\title{
A Religion of the Book? On Sacred Texts in Hinduism
}

\author{
Robert Leach, University of Zürich
}

\begin{abstract}
In this article I provide an overview of the identity, role and function of sacred texts in Hinduism. Hinduism's tremendous diversity extends to the numerous ways in which different types of texts have been identified as sacred and used by Hindu practitioners. It would be a mistake to attempt to summarise the role of sacred texts in the lives of Hindus, since different texts have had different roles and performed different functions. In the following, therefore, I address what I identify as the four major types or categories of sacred text in Hinduism independently of each other, while noting the commonalities they share, and some of the ways in which texts belonging to the different categories have engaged with one another. The first three of the four categories of text I address consist of Sanskrit works, and the names of the categories are Sanskrit terms which have been applied by Hindus to their own literature (Veda/Śruti; Smrti; Tantra, Ägama and Stotra). In the final section, I depart from using "insider" terminology and address "sacred texts in vernacular languages".
\end{abstract}

Keywords Hinduism, sacred text, scripture

\section{Introduction}

This article is intended as an overview of the identity, role and function of sacred texts in Hinduism. Such an endeavour is beset with potential difficulties, not least in that Hinduism is itself a modern term, not used before the latter half of the $18^{\text {th }}$ century, and with no obvious equivalents in Indic languages before that time. Applying the term Hinduism to the past, then, is frequently problematic, though in general modern scholarship is in agreement that there are important continuities between the present-day phenomenon of Hinduism and codes of ritual practice, narrative traditions and religious customs that emerged in South Asia in the second half of the first millennium before the Common Era (BCE).

Identifying the "scriptural" or "sacred" literature of Hinduism is also significantly more complex than with other major religions such as Buddhism, Christianity, Judaism and Islam. Hinduism has no historical founder, no universally recognised hierarchy of authority, no universally adhered to teachings, practices or beliefs, and there is no single sacred text to which all Hindus pay tribute. Using concepts such as "scripture" and "sacred text" creates its own problems when confronting the diverse textual traditions and linguistic cultures that are a part of Hinduism, and for this reason, I structure the following account around terms which Hindus themselves have used. These terms belong to Sanskrit, the oldest of South Asia's living languages, and the language in which by far the most influential and widely disseminated texts in Hinduism, at least until the middle of the second millennium CE, are composed. The overwhelming priority given to Sanskrit literature in the following account is itself not unproblematic, since the vast majority of the people we retrospectively identify as Hindu have not used or understood this language. However, it is also unavoidable given that Sanskritic culture has left by far the largest literary record of any translocal, 
premodern language in South Asia, and that those excluded from this culture often left no record at all.

\section{The Vedas and Śruti}

The period during which the many texts included within the Veda (literally "The Knowledge") were composed, collected and arranged into a canon lasted approximately 1200 years (c. 1600-400 BCE). The Vedic texts were orally composed and were transmitted from teacher to pupil, as they are to this day in some parts of South Asia, without the aid of script. ${ }^{1}$ This has necessitated exceptional feats of memorisation and an extremely strict emphasis on correct recitation. Although archaeology is increasingly shedding light on aspects of Vedic society and religion, these texts are our most important source of information about the Vedic period. Whilst precise dates for individual Vedic texts are extremely difficult to establish, and are likely to remain so, the chronology of their composition, and of the distinct historico-linguistic layers internal to individual texts, is less so, and has persisted as a major focus of scholarly research since the pioneering philological work of the great German Indologist Hermann Oldenberg (1854-1920). It was Oldenberg, also, who first mapped in detail the southeastward expansion during the Vedic period of the Sanskrit speaking "Āryans" (ärya, "noble") whose priestly class composed the Vedas. More recent scholarship has sought to trace this movement with greater precision and to explain the reasons for its occurrence. Since the majority of the texts are oriented towards ritual practice, and comprise mostly unsystematically formulated liturgical material for the performance of the Vedic fire sacrifice, information about Vedic society, myth, religious belief, the intricacies of ritual, and canon formation, has to be laboriously extracted from the texts, and a great deal of past scholarship on the Vedas has been devoted to piecing together such information.

The earliest and most prestigious text within the Vedic canon is the Rgvedasamhita ("Collection of the Knowledge of Verses"), an anthology of 1,028 poems arranged in ten books or "cycles" (mandala), the vast majority of which were composed in the Greater Punjab in the northwest of the subcontinent between c. 1600 and 1200 BCE. ${ }^{2}$ These "poems" consist primarily of verses of praise and invocation, addressed to various gods and local tribal chieftains, which were intended for recital at the annual Soma sacrifice, centred on Indra and celebrated at New Year. Principal among the gods addressed are Indra, the god of war and paradigmatic Āryan alpha male; Agni, the deified ritual fire into which sacrificial offerings to the gods are made; and Soma, the deified sacred drink (and the plant on which the drink is based).

The poems often contain the names of their authors, as well as the names of the clans or tribes to which these authors belonged. These poets did not intend their compositions to be collected alongside poems by members of other tribes, with whom

\footnotetext{
${ }^{1}$ Evidence suggests that writing was introduced into the Indian subcontinent by the Persian conquerors of Gandhāra (in the extreme northwest) in the second half of the $6^{\text {th }}$ century BCE. Gandhāra is the homeland of what is possibly the earliest Indic script, namely Kharosththī, which is derived from the Aramaic script. The earliest evidence for writing in Kharoșthī, or indeed in any Indic script, is dateable to the reign of Aśoka (c. 269-232 BCE).

${ }^{2}$ There is, as yet, no complete, reliable English translation of the Rgvedasamhita, though this is set to change in 2014 with the greatly anticipated forthcoming translation of Jamison and Brereton.
} 
there was often conflict, and to be anthologised in the Rgvedasamhitā. This occurred in a later period (c.1200-1000 BCE) in the region of Kuru, southeast of the Greater Punjab, once Kuru kings had unified most of the 50 or so Rgvedic tribes to form what has been called the first "state" on Indian soil. This period remains something of a dark age in Indian historiography, but its importance to subsequent developments in South and Southeast Asian society and religion is paramount, since it was in this time and place that the priestly class, the Brahmins, formed an alliance with the warrior nobility and, as documented in one of the latest Rgvedic poems, began to promote the idea that society consists of four social classes. It was also here that Rgvedic ritual practices were systematically reformulated in the creation of the new, elaborate Śrauta rites, some of which are performed in traditional parts of India and Nepal to this day. These innovations resulted in the production of new ritual texts which were assembled according to the division of priestly labour in the new rites: the Sämavedasamhitā ("Collection of the Knowledge of Melodies") being the property of the priests responsible for singing the verses of the Rgvedasamhitā; ${ }^{3}$ the Yajurvedasamhitā ("Collection of the Knowledge of Ritual Formulae") that of the priests who perform most of the ritual actions, accompanying them with the recitation of ritual formulae (mantra); and the slightly later, and to many minds inferior, ${ }^{4}$ Atharvavedasamhita ("Collection of the Knowledge of [the sage] Atharvan") that of the priests responsible for rectifying any mistakes in the performance with the recitation of incantations. Each of these collections borrowed and adapted verses from the Rgvedasamhitā. ${ }^{5}$

The Vedic Samhitās (Rg-, Sāma-, Yajur-, Atharva-) are the foundational texts of the four Vedas: the Rgveda, Sāmaveda, Yajurveda and Atharvaveda. During the next five or six hundred years the priests of each Veda considerably enlarged their textual corpus by composing numerous other works. These fall into four main text-types, listed here according to the approximate chronology of their composition: Brāhmana (exegetical texts, interpreting the rituals and explaining their hidden meanings); Áranyaka ("wilderness texts", discussing the more secret and dangerous rituals); Upanisad (secret teachings, containing early metaphysical speculation and introducing important new ideas into the Vedic worldview such as rebirth, the character of which is dependent on the quality of one's actions (karma), and moksa, liberation from rebirth); and Kalpasūtra (discussed below). To further complicate issues, since the time succeeding the anthologisation of the Rgvedasamhitāa, all Vedic texts, including the Samhitās, have existed in multiple versions - a consequence of local differences in ritual and pronunciation between different groups of Brahmins within each Veda. These differences led to the recognition of separate Vedic schools $(s \bar{a} k h \bar{a})$, each of them associated with a particular Brahminical community in a particular geographic area. This meant that, for virtually the entirety of the Vedic period, there was no Vedic "canon" to speak of, only a canon of texts accepted by each school (Witzel 1997).

\footnotetext{
${ }^{3}$ Thus, the Sämavedasamhitā consists almost entirely of verses from the Rgvedasamhitā. The ritual role of the priests associated with the Rgvedasamhita was the simple recitation (rather than singing) of its verses.

${ }^{4}$ Certain conservative traditions have never accepted the authority of the Atharvaveda, and recognise, therefore, only three Vedas.

${ }^{5}$ These adaptations show that although the Rgvedasamhitā was clearly highly regarded, it was not yet sacrosanct.
} 
This situation changed around the end of the Vedic period (c. 500-400 BCE), when a final process of Vedic canon-formation took place in northeast India (the region of modern-day Avadh and Bihar). Here, all texts, other than the Kalpasūtras, ${ }^{6}$ belonging to all schools in each of the four Vedas were declared to be equally authoritative and part of the unitary Vedic canon, from this time forward spoken of as "the Veda" or Śruti. Very little was added subsequently. The term śruti, meaning "that which is heard", indicates the new idea that the unitary Veda has no author/s, but was revealed to and seen by inspired primordial seers $(r s i)$ who recited it to their pupils - thus, the Veda has been heard by all generations of Veda-reciters subsequent to the first. The system of Vedic exegesis which asserted the unity and authorlessness of the Veda became known as the Mīmāṃsā. Later Mīmāmssā authors argued for the eternality and authorlessness of the Veda, and of the sacred Sanskrit language, on the grounds that since there is no recollection of an author (or first reciter), we have no basis to assume the existence of one, or reason to doubt that persons in the past learnt the Veda just as those in the present do i.e. by hearing it recited by a teacher (McCrea 2011). The idea of the eternality and authorlessness of the Veda was very influential, and was later accepted by several important philosophical schools, including those located within the tradition of Vedānta, based on the exegesis of the Upanisads. However, it was not accepted by all. Monotheistic traditions first referred to in the later portions of the Sanskrit Mahābhārata (c. $3^{\text {rd }} 4^{\text {th }}$ Century CE), attributed authorship of the Veda to God, as did, from around the $6^{\text {th }}$ century CE, the influential philosophical school of Nyāya.

The Veda has occupied an ambiguous position in Hinduism. On the one hand, many Hindus have proclaimed it their most authoritative and sacred body of literature. On the other, for the past two thousand years its contents have been almost completely unknown to the vast majority of Hindus, and have had virtually no relevance to their religious practices. In the last centuries before the Common Era, access to the Vedic texts was limited to male members of the three highest social classes, and since at least the second century CE, Hindu law-makers have declared that only male Brahmins are eligible to study the Veda. Between then and now, the great majority of the people we retrospectively identify as "Hindu" have been deliberately excluded from the Veda, and for most of this period we have little means of knowing whether such people accepted its authority. In ancient India, the maintenance of the Veda's exclusivity was largely dependent on two factors: first, that it was prohibited to commit the Vedic texts to writing; second, that Brahmins were the guardians not only of the Vedas, but also of Sanskrit. By excluding all except male Brahmins from learning Sanskrit, the Veda was kept out of the majority's reach. However, after the Sanskrit of the Vedas had developed, in the last centuries BCE, into the distinct, post-Vedic "Classical Sanskrit", the content of the Vedas became inaccessible even to many Brahmins. Already in the Mānavadharmaśāstra, a Brahminical text composed probably around the $2^{\text {nd }}$ century CE (Olivelle 2004), there is a reference to Brahmins who recite the Veda but do not understand it, and ethnographies attest to the existence of such persons today. This neglect of the content of the Vedas, together with the sustained emphasis on their correct recitation, signals the prevalent belief that the sacredness of these texts is in their sounds rather than

\footnotetext{
${ }^{6}$ Hence, the Upanișads are considered to represent "the end of the Veda" (Vedānta), and are indeed often referred to in this way.
} 
their meaning. Thus, to recite correctly, or to hear such a recital, is intrinsically efficacious.

According to Watts (2006), texts function as scriptures through the ritualisation of three primary "dimensions": semantic, performative and iconic. If we apply this typology to the Veda, for the majority of its history we can say that its semantic dimension has counted for very little, and that its performative dimension has been ritualised to by far the greatest degree. There is also textual evidence starting from around the end of the first millennium CE that, in spite of continued prohibitions against writing down the Vedas in some quarters, manuscripts of Vedic texts have been worshipped by theistic traditions, normally alongside other manuscripts, as physical manifestations of god's knowledge. However, this practice appears never to have been the predominant mode of engaging with Vedic texts.

Finally, the authority of the Veda has also been implemented outside of the ritual context. Perhaps the most striking example of this is that, up until modern times, Hindu legal traditions have affirmed that the Veda is, theoretically, the highest authority in all matters pertaining to correct behaviour (dharma), both public and private. In practice, though, the highest authority has in fact rested with an elite group of specialists in such matters, namely "those who know the Veda", and the legitimacy of these specialists' pronouncements on legal issues has been determined a priori by the identity of their authors as knowers of the Veda, rather than a posteriori by appeal to particular passages in Vedic texts. In various different ways, the Veda has provided a transcendent source of authority for Hindu traditions.

\section{Smrti}

As a textual category, Smrti, meaning literally "memory, remembrance", emerged later than Śruti and has had a much broader purview. Before it came to denote a specific body of literature, the term smrti indicated "remembered norms" viz. "tradition", especially as an authoritative source of knowledge, alongside the Veda, in matters relating to proper conduct (dharma). When it came to refer to texts, during the $2^{\text {nd }}$ century BCE at the earliest, Smrti referred exclusively to the genre of Dharmaśāstra (discussed below), and this appears to have remained the case for several centuries (Brick 2006). While both the early history of Smrti and its later elaboration and rationale in Mīmāmsā apologetics have been studied in detail in recent years, there is as yet no scholarly consensus as to precisely when, and with what justification, texts other than the Dharmaśāstras began to be included within the category. However, it is clear that the definition proposed by the $5^{\text {th }}$ century Mìmāmsā author Śabara allows a considerably broader conception of Smrti than had been admitted in earlier times. In his commentary on the foundational text of his school, the Mìmāmsāsūtra (c. 200 BCE?), Śabara argues that Smrti designates those texts which retain the essential purport (although not the exact wording) of Vedic texts which have been lost or forgotten, but whose former existence can be inferred from the fact that authoritative persons (i.e. Vedic Brahmins) still follow their dictates. Seen in this way, as Pollock (1997) points out, Smrti texts are themselves Vedic. This definition of Smrti opened up the category to such an extent that it was never really closed thereafter, and there has been no universal agreement since Śabara as to which texts can be included as Smrti, and which cannot. In the following, I will address the 
few texts which are generally held to be uncontroversially included within this category.

\section{i.) Śāstra: Vedānga and Dharmaśāstra}

In modern Sanskrit-English dictionaries, the term śāstra, from the verbal root śās-, "to instruct", is commonly given as a Sanskrit term for scripture. This may be partially justified insofar as it was used, from an early period, to denote the Veda, but in reality Śāstra designates a much broader class of texts, many of which would not ordinarily be understood as "scripture", however vaguely defined. The term appears to have originally signified the technical treatises dealing with the six disciplines recognised as being ancillary to the study of the Veda (Olivelle 2010). The six disciplines, known collectively as Vedānga ("the limbs of the Veda"), are ritual (kalpa), astrology and astronomy (jyotisa), phonetics (sikșā), prosody (chandas), etymology (nirukta), and grammar (vyākarana). The authoritative texts which address these disciplines, nearly all of which were composed after the Vedic period, are generally aknowedged to have been authored by humans. ${ }^{7}$ The earliest of these belong to the genre of Kalpasütra ("Aphoristic Rules on Ritual") - the only Vedānga works which will detain us here in which there are three kinds of texts: Srautasūtra (instruction manuals for the performance of public Vedic rites); Grhyasūtra (appended to the Śrautasūtra; manuals for domestic rites, especially the rites of passage); and Dharmasūtra (normative and descriptive guides to all aspects of correct individual and social conduct as well as to matters relating to civil and criminal law). Although the Kalpasūtras are Vedic in the sense that they are composed in Vedic Sanskrit and are identified as belonging to one or other of the Vedic schools $(s \bar{a} k h \bar{a})$, they have never been considered a part of Śruti. This is most likely a consequence of their relatively late composition and of the fact that they are essentially instruction manuals for the correct performance of actions enjoined in the earlier literature. However, although they have been excluded from what was originally (and in some senses remains) the most authoritative body of Sanskrit literature, the Kalpasūtras have arguably played a more important role in the day-to-day lives of Hindus than has any Sruti text. In order to explain this, it will be helpful to briefly address the Śrautasūtras and Grịyasūtras together, and then to look at the Dharmasūtras.

Although plenty of information concerning the Śrauta rites can be extracted from the earlier Brāhmanas, these texts do not offer priests detailed, step-by-step guides to carrying out the rituals. This is the reason for which the Śrautasūtras were composed and have been transmitted between generations of priests for two and a half thousand years. Unlike the Śruti texts, there are no intrinsic benefits to be had from reciting and hearing or reading the Vedic Suttras other than the communication and acquisition of the information they contain - their value is in their content. ${ }^{8}$ As many of the Śrauta rites have been replaced by other forms of ritual (see below) and have become obsolete, or only rarely performed, so the Śrautasūtras have declined in importance.

\footnotetext{
${ }^{7}$ However, their authors are also often considered to be "seers" (rși), and for instance Patañjali, author of a $2^{\text {nd }}$ century BCE grammatical text, has, from around the $13^{\text {th }}$ century, been considered an incarnation of Śeșa, the divine grammarian.

${ }^{8}$ However, there are references in later literature (from the c. $9^{\text {th }}$ or $10^{\text {th }}$ century CE) to these texts being worshipped, alongside the Vedas and other works, in their written form.
} 
The Gṛhyasūtras, on the other hand, have retained a more central role in the lives of Hindus, a consequence of their subject matter - domestic ritual - and the greater breadth of their intended audience - male householders belonging to the three highest social classes. Chief among the domestic rites enjoined in the Grhyasūtras are the socalled rites of passage or, better, "life-cycle rites" (samskāra), the most important of which are those performed at the conception of the embryo, birth, initiation into Vedic study, marriage, death, and the worship of the departed ancestor. Each of these are still performed today within traditional Brahminical families.

Although the content of the Dharmasūtras ("Aphoristic Rules on Proper Conduct") overlaps to a considerable degree with that of the Grihyasūtras, containing as they do a wealth of information on ritual performance, especially on the life-cycle rites and the reparatory rites to be performed in case of mistakes in the ritual procedure, these texts also came to represent a tradition independent from the other Vedic Kalpasūtras, and indeed from the Vedic schools in general. The name of this independent tradition is Dharmaśāstra, and it is principally constituted by the Dharmasūtras, orally composed from c. 300-50 BCE (only four of these texts are extant), and several later works in verse, principal among which is the Mānavadharmaśāstra ("The Law Code of Manu"), also called Manusmrti, most likely composed during the $2^{\text {nd }}$ century CE. These texts offer both prescriptive and descriptive accounts of correct ritual, social and ethical behaviour, the first two of which differ according to one's social class and the stage of life one is at. More than religious belief or cultural custom, it is the dharma of the Dharmaśāstra that has been central to the identity of Hinduism as a religion.

\section{ii.) Itihāsa and Purāṇa}

The category of Itihāsa ("[narratives which tell of] the way things were") includes India's two great epics, the Mahābhärata and the Rāmāyana. Both of these have existed, for over two thousand years, in a variety of artistic genres including dance, theatre, film and television, as well as in numerous literary versions in many of the vernacular languages of India and Southeast Asia. ${ }^{9}$ In both cases, their earliest extant forms are immensely long Sanskrit texts in verse, the bulk of which were orally composed over several centuries between c. $400 \mathrm{BCE}-400 \mathrm{CE} .{ }^{10}$ This period saw myriad changes in the religious and political culture of northern and central India, many of them brought about by the rise to prominence of Buddhism and, to a lesser extent, Jainism. These changes and their far-reaching consequences are too numerous to list here, though mention should be made of the transformation of the Vedic priesthood (the Brahmins) into proponents of a tremendously successful religious and socio-political ideology based on Brahminical superiority (see Dharmaśāstra), and of the emergence of monotheistic traditions which, without wholly repudiating the authority of the Veda and its sacrificial cult, established new forms of worship centred upon the veneration of images of god in temples and at shrines. The foundations laid

\footnotetext{
${ }^{9}$ Popular retellings in modern times include Peter Brook's nine hour play The Mahabharata (1985), and the hugely popular Hindi TV serials of the Ramayan (dir. Ramanand Sagar, 1987-8) and Mahabharat (dir. Ravi Chopra, 1988-90).

${ }^{10}$ The Mahābhärata is approximately four times the length of the Bible, the Rāmāyana about the same length as the latter.
} 
by these innovations gave support to a religious culture which is retrospectively identified as "Hindu" as distinct from "Vedic".

Although the Mahābhārata and Rāmāyaṇa include, though by no means confine themselves to, much of the same sort of religious, ethical and metaphysical doctrine as can be found in earlier Sanskrit literature, they do so within a framework derived from more popular (as opposed to priestly) storytelling traditions. Both were recited and performed by bards at the courts of rulers and, unlike the Veda, they were not memorised word for word but could incorporate new themes, subplots and characters in each retelling - a detail that accounts for their long gestation periods as well as their great length. At some stage around the beginning of the Common Era, both texts began to be written down, and their transmission passed into the hands of Brahmins. However, unlike the texts covered thus far in this article, the Mahābhärata and Rāmāyana claim to address themselves to women as well as men, and to members of all social classes. As with the Vedas, regional and cultural differences among the Brahmins responsible for transmitting the Sanskrit epics led to there being numerous versions of both texts, and both have been handed down in two principal recensions, one from the north and one from the south of India. In the $20^{\text {th }}$ century, Indian scholars compiled critical editions of the Sanskrit manuscript traditions of both texts (in the case of the Mahäbhärata, 1,259 manuscripts were collated) and much of the subsequent scholarship on Itihāsa has been based on these editions. While the identification and dating of the two texts' multiple layers has dominated philological work, there have also been numerous recent studies on the religious, philosophical, political and aesthetic dimensions of the epic traditions, as well as, for instance, structuralist and gender-based approaches to epic narratives.

The central story of the Mahābhärata tells of a bitter succession conflict, culminating in an 18-day war, between two sets of cousins for the ancestral realm of the Bhārata clan, the kingdom of Kurukṣetra in northern India. The most celebrated (and studied and translated) section of the Mahābhärata is the Bhagavadgìta ("The Song of the Lord"), which has often been treated, both by medieval commentators and modern scholars, as an independent text. ${ }^{11}$ As with the Mahäbhärata in general, scholarship on the Bhagavadgīta has been dominated on the one hand by philological approaches, and on the other by approaches which take the text as a meaningful whole and interpret it according to different theoretical perspectives. ${ }^{12}$ The Gitta , as it is affectionately known, takes place about midway through the story as the two sides are lining up for battle, and it consists mostly of Kṛ̣na's exhortation to Arjuna, one of the major heroes of the Mahābhärata, to go forth and fight. Arjuna's unwillingness to do so derives from the fact that many of his family members and former teachers are among the enemy. Krṣna, who is ostensibly Arjuna's charioteer, reveals himself to be the supreme god, manifest on earth in order to restore dharma. His exhortation primarily involves a discussion of traditional concepts (e.g. sacrifice, dharma and karma) set within a new monotheistic framework. In several places the Gìta describes itself as an upanisad, thus laying claim to the status of Śruti, and indeed for most Vaiṣnavas (worshippers of Viṣnu), and for many non-Vaiṣnava Hindus, it is among the most sacred of all texts, and is in some parts of India an object of temple worship.

\footnotetext{
${ }^{11}$ The first translation into a European language was by Charles Wilkins into English in 1785. Subsequent important translations of the text include those by A. W. von Schlegel into Latin (1823) (which attracted the attention of G. W. F. Hegel and others), and Richard Garbe into German (1905).

${ }^{12}$ Malinar (2007) combines both approaches.
} 
Scholars generally agree that the identification of Kṛṣna with Viṣnu belongs to the latest layers of the Mahābhärata (it is not found in the Gitta itself). It is also in these later layers that the Mahäbhārata calls itself the "fifth Veda" and claims the mythical seer Vyāsa as its author.

The Rāmāyana ("The Career of Rāma"), which tells the story of the exemplary warrior-prince Rāma and his retrieval of his devoted wife Sìtā from her evil abductor King Rāvana, also claims in one of the apparently later layers of the text that it is equal in authority to the Veda. The Rāmāyana, though, presents itself as a literary work, indeed as the very first work of poetry, composed by the inspired poet-seer Vālmīki, which perhaps explains why F. Max Müller, in his preface to The Sacred Books of the East (1879) declared that it is not a "Sacred Book", calling it instead a "national epic". Certainly the Rammāyana has held something akin to the status of national epic - as Goldman and Sutherland Goldman (2010) write, "Its episodes and characters are known to every stratum of [Indian] society, every region of the country, and the adherents of every religion." However, it has been interpreted especially as a treatise depicting the ideal Hindu state, a sort of poetical rendering of Dharmaśāstra, and has been used by Hindu rulers, especially against Indian followers of Islam, to justify a particular idea of divine Hindu kingship. Further, its influence extends well beyond South Asia, as is evident from the fact that versions of the Rammayana have been written in, for instance, Old Javanese $\left(9^{\text {th }}-10^{\text {th }}\right.$ century), Khmer $\left(16^{\text {th }} / 17^{\text {th }}\right.$ century), and Thai ( $18^{\text {th }}$ century). Moreover, its hero Rāma is worshipped by millions of Hindus, either as the supreme god or as an incarnation (avatāra) of Viṣnu. There are temples to Rāma, as well as depictions of scenes from the Ramanyana on temple walls, all over India, as well as numerous temples to its other central characters. For many millions of the Hindus who worship in these, the Rammayana is the exemplary narrative of god's life as a man engaged in the destruction of evil and the restoration of dharma. Like the Mahābhārata, sections of the text are regularly declaimed at festivals and in temples across South Asia, a practice which is considered meritorious both for the reciters and the audience, even if the majority among the latter do not understand Sanskrit.

The term Purāna ("Ancient [Tales]") denotes a vast body of mostly Sanskritic literature which began to be written down in the early centuries of the Common Era, as well as a vibrant but little-studied performative tradition in various vernacular languages which continues to this day. ${ }^{13}$ According to tradition, Vyāsa, the mythical author of the Mahābhärata, is also the author of all the Purānas. There are said to be 18 Major and 18 Minor Purānas though in reality there are many hundreds of texts in this genre. Like the Sanskrit epics, the Purānas allign themselves with the Veda, the rituals and myths of which they appropriate, adapt and expand to fit with their own monotheistic (or, better, henotheistic) theology. ${ }^{14}$ As well as appropriating Vedic rituals and myths, the Purānas also consciously appropriate the Veda's scriptural status, and many Purānas explicitly call themselves Purānaveda and identify themselves as transmitting the infallible knowledge of the Veda, in the form of Purāna, to the general populace (Smith 1994). Thus, in common with Itihāsa, the

\footnotetext{
${ }^{13}$ There is also a smaller, albeit substantial, corpus of Jain Purānas, written in a variety of South Asian languages, including Sanskrit. These will not be discussed here.

${ }^{14}$ The Purānas continue theistic trends observable in the later layers of the epics, with certain texts, such as the Viṣnu Purāna and the Devī Māhātmya of the Mārkaṇ̣̂eya Purāna clearly emphasising the sectarian worship of one particular god or goddess.
} 
Purānas claim to be accessible to women and to members of all four social classes (varna). Unlike the epics, these texts do not revolve around a central narrative: their contents are a miscellaneous collection of complex cosmologies, elaborate genealogies, stories of the exploits of deities and kings, and descriptions of law codes, rituals and pilgrimages to holy places (many of which are still adhered to or undertaken today). Some of these texts are very long (in several cases considerably longer than, for instance, the Rämāyaṇa), though they are not intended to be recited or read from beginning to end. ${ }^{15}$

In keeping with the idea that the Purānas occupy the same textual territory as the Veda, they often contain passages (called phalaśruti, "the fruits of hearing [the text]") which list the worldly and soteriological benefits that can accrue from hearing part of the text in recital. In many cases, these "fruits" are assured to the listeners regardless of whether or not they understand the verses in question, and irrespective of their own personal religious allegiance. In other words, according to the authors of these passages, it is the very sounds of the Purānas that are sacred, and in these contexts, as with the Vedas, sound has primacy over content. In addition, the Purānas also offer some of the earliest examples, within a Hindu context, of the idea of the holiness of manuscripts. Many Purānas list the soteriological benefits that accrue from copying manuscripts of one or other Purāna, from keeping, displaying and worshipping a Purānic manuscript in one's house or temple (in which cases all members of the household or temple are eligible to receive benefits), and from passing such a manuscript on to others. In these cases, then, the written form of a Purāna functions in a similar way to its sonic form: to use Watts's (2006) terminology, in these instances the ritualisation of the performative and iconic dimensions of Purānic scripture takes precedence over the ritualisation of its semantic dimension.

On the other hand, the content of the Purānas has a much more important place in the Hindu imagination than has, for example, the content of the Vedas. A great many of South Asia's most popular stories of gods, sages and demons, known to millions of Hindus and retold today in multiple media, are found in the Purānas. Especially important in this regard is the Bhāgavata Purāna, composed in South India in the $9^{\text {th }}$ $10^{\text {th }}$ century CE. This work, which remains the most studied and translated of all Purānas, and which has inspired a large body of commentarial literature, is a central religious text for the Gaudiya Vaisnava tradition, founded in $16^{\text {th }}$ century Bengal. The main focus of the Bhāgavata Purāna is the adoration of Kṛ̣na as the supreme god, and it tells numerous stories of Kṛ̣na's exploits, including his romantic adventures with the cowherd girls in its famous tenth chapter, which would already be known to its intended audience (Narayana Rao 2004). For worsippers of Kṛ̣na, including Gauḍiya Vaiṣnavas, the Bhāgavata Purāna is recited, listened to and read, therefore, not in order to impart or acquire information about Kṛṣna, but as means of celebrating and expressing devotion to him.

\section{Tantra, Āgama and Stotra}

\footnotetext{
${ }^{15}$ Accordingly, much of the scholarship on the Purānas has approached these texts through particular themes, concentrating on recurrent myths and modes of worship or literary style etc. rather than treating each text as an individual whole.
} 
From around the $5^{\text {th }}$ or $6^{\text {th }}$ century CE, certain sectarian theistic traditions in North India began producing scriptural works, commonly bearing the suffixes tantra ("ritual system") or āgama ("that which has come down"), which often present themselves as constituting a higher and more specialised revelation than that presented by the Veda. ${ }^{16}$ Within the Hindu context, the majority of these texts claim to have been authored by either Śiva or Viṣnu, and the followers of such Tantras or Āgamas are called, respectively, Śaiva and Vaiṣnava. There are several distinct Śaiva and Vaiṣnava Tantric traditions, and these are primarily distinguished from one another by the mantras they use in rituals, and by their scriptural canons. The contents of Tantric texts are predominantly liturgical: many are primarily intended as manuals for the Tantric preceptor carrying out the initiation rites (by which one becomes a member of the tradition) and the preparation for and performance of the post-initiatory worship of a range of deities. ${ }^{17}$ This worship may take place in a temple or in private. The texts also list the rewards, including supernatural powers and liberation from worldly existence, that accrue from undergoing initiation and worshipping god or gods in the ways prescribed. However, these texts are not merely "manuals" for the preceptor, they also address various theological and cosmological topics, and many of them consist of parts apparently intended for the initiate alongside the parts intended for the preceptor. Not only is access to these texts prohibited to the uninitiated, even for those who have undergone initiation access would be mediated by one's preceptor or guru. Some texts declare that they are to be read only with a guru, and that it is a sin to read them otherwise, and some use deliberately obscure language and references in an apparent attempt to obstruct "outsiders" from accessing their content. ${ }^{18}$ For such reasons, the Tantras are often described as being "esoteric", in contrast to Itihāsa and the Purānas which are, are at least theoretically, available to everyone, including those who follow the Tantras. Tantric texts, and the practices they enjoin, are exclusive only insofar as they are the exclusive preserve of those who have been initiated into the tradition: they do not make exclusive demands on their followers, who are allowed, and in many cases encouraged, to practice the more mainstream Purānic rituals as well as those of the Tantras.

The Tantras and Āgamas also have much in common with the Purānas and, like the Purānas, they frequently list the soteriological and worldly benefits that ensue from hearing a particular text being recited, or from worshipping the manuscript of this or that text. One Vaiṣnava Tantra from the $12^{\text {th }}$ or $13^{\text {th }}$ century even declares that, for a member of that tradition, it is enough to recite the names of the Tantras of that tradition to ensure that one will be liberated from rebirth at death. Many works instruct initiates to worship the text by which they received initiation, and to safeguard it from falling into the wrong hands. The importance of texts for Tantric traditions is conveyed by the fact that in this context the term tantra can mean both

\footnotetext{
${ }^{16}$ Not all Tantras and Āgamas present themselves as being superior to the Veda. For instance, the South Indian Vaikhānasa tradition, which produced a large body of scriptural literature from the c. $9^{\text {th }}$ century, refers to its texts as Tantra and Āgama, but identifies itself as a Vedic school. In addition, there are Jain and Buddhist Tantras, which do not identify themselves in relation to the Veda at all.

${ }^{17}$ There is no uniform rule as to who is eligible for Tantric initiations - particular traditions have their own criteria, which are liable to change over time. Some traditions accept only male members of the three highest social classes, others accept male and female initiates from all social classes.

${ }^{18}$ Such strategies have, historically, affected scholarship on the Tantras. In the last 30 years or so, however, real advances have been made in this area, and today the text-critical study of the Tantras and their commentaries is one of the fastest growing areas in South Asian textual scholarship.
} 
"text" and "tradition": perhaps more than any other Hindu traditions, Tantric traditions are "religions of the book". Many of these works also present themselves as being actual physical manifestations of god, so that in reading, reciting or worshipping the text the adept is directly worshipping god.

The genre of Stotra ("Hymn of Praise") shares several features with the Tantras and Āgamas. There are innumerable texts of this type, composed in many South Asian languages, and they are still being composed and published to this day. Stotras are mostly short works in verse which directly address a deity, offering praise and seeking favours of a salvific or "worldly" nature. Many Stotras are contained within larger works (including the Yajurveda, the epics, the Purānas and the Tantras or Âgamas), though they have often been used independently, and many Stotras constitute independent texts in themselves. Śiva and Viṣnu are the most commonly addressed deities alongside the goddess. Stotras are often sung in temples during worship $(p \bar{u} j \bar{a})$, where they can function both as devotional hymns, understood as "offerings" to the divine addressee, and as liturgical texts accompanying the performance of certain rites. It is commonly understood that the recitation of such hymns, seen as an act of worship in itself, automatically brings benefits to the reciter. Unlike the Tantras or Āgamas, Stotras are not the exclusive preserve of certain sects, and many are used across sectarian boundaries. Some Stotras consist entirely of the different names by which the god to whom they are addressed is known. Several of the most popular of these Nāmastotras ("Hymns of Praise of [God's] Names") are addressed to Rāma (or Rām in the now more commonly used Hindi).

\section{Sacred Texts in Vernacular Languages}

Relative to the large body of scholarship on Sanskrit literature, the study of the sacred vernacular literatures of South Asia is still in its infancy, with the majority of texts still in need of critical editions. A consquence of this is that general overviews of Hinduism and its sacred literature have tended to underestimate, or else completely ignore, the important role of vernacular texts and traditions. To cite just one example, Everyman's Library's Hindu Scriptures has, over the course of three editions (1938, 1966, 1996) and three different editors, included, in part or whole, 19 texts, all of them in Sanskrit. And yet, in terms of the sheer numbers of Hindus who have identifed, utilised and responded to sacred literature, sacred texts in verncaular languages have enjoyed a much more prominent position over the past millennium ("the vernacular millennium" in the words of Pollock 2006) than have any Sanskrit works which, for social and linguistic reasons, are accessible only to a minority. It is commonly said that Sanskrit is the sacred language of Hinduism, yet this claim obscures the fact that many vernacular languages have also been regarded as sacred, and many vernacular texts considered, by their followers, equal in authority to the Veda.

The relations between Sanskrit and vernacular, and between the Veda and vernacular sacred texts, is often addressed directly by the latter. The South Asian vernacular language with the longest literary history (approximately 2000 years) is Tamil, and it is in Tamil literature, between the c. $10^{\text {th }}$ and $12^{\text {th }}$ centuries CE, that we first find vernacular texts referred to as Veda and declared superior to the Sanskrit Veda since they are available to everyone regardless of social class. Perhaps the most 
important Tamil text equated with the Veda is a large collection of devotional (bhakti) poems addressed to Viṣnu, the Nālayyira Divyaprabandham ("The Divine Collection of 4000 [Verses]"), compiled around the $10^{\text {th }}$ century CE by Nāthamuni, the alleged founder of the still-living Śrīvaiṣnava tradition. The Śrīvaiṣnavas call this text the "Tamil Veda", and from around the $12^{\text {th }}$ century, they have recited sections from it alongside sections from the Sanskrit Vedas during temple worship, at weddings and funerals, and during daily worship at home. The poems in this collection are thought to have been revealed by Viṣnu through the 12 Ālvār poets (c. $7^{\text {th }}-9^{\text {th }}$ centuries CE), all of whom are worshipped as saints, in the form of icons, in Srīvaiṣnava temples. The most sacred among the poems collected in the Nālayira Divyaprabandham is the 1000 verse Tiruvāymoli of Nammālvār, a poet belonging to a peasant caste who lived in the c. $9^{\text {th }}$ century CE. The Tiruvāymoli is thought by Srīvaisnavas to contain the essence of the Sāmaveda. Among the other Ālvār poets, the most notable and arguably the most popular, is Ānțāl, the only female Ālvār. There exists a comparable collection of Śaiva bhakti poetry in Tamil, composed from the c. $6^{\text {th }}-10^{\text {th }}$ centuries by the 63 Nāyanār saints, and collated in the $11^{\text {th }}$ century Tirumurai, later to form part of the scriptural corpus of the Tamil Śaiva Siddhānta, a distinctive bhakti-oriented school of a pan-Indian Tantric tradition. In the following century the poet Cekkilār composed the Periyappurānam, a hagiography of the Nāyanār saints that was revered as the "fifth Veda", and eventually incorporated into the Tirumurai.

The second longest literary history among the Dravidian languages of South India belongs to Kannada, and the earliest extant sacred texts in this language are the devotional Vacanas ("Sayings"), short prose poems addressed to Siva, composed by male and female members and forebears of the Vīraśaiva or Lingāyat movement from the $11^{\text {th }}$ or $12^{\text {th }}$ century CE onwards. Basava, the alleged $12^{\text {th }}$ century founder of this "bhakti protest movement" (Ramanujan 1973), which rejects the Veda and caste hierarchy, formulated the following oft-quoted pithy dismissal of Vedic tradition: "Parrots recite. So what?" (ibid.: 76). Other important sacred works in South Indian vernacular languages include Nannaya's Mahäbhäratamu, an $11^{\text {th }}$ century retelling of the Mahäbhärata in Telugu, and two versions of the Rämāyana in Malayalam: the $13^{\text {th }}-14^{\text {th }}$ century Rammacaritam, known to have been ritually recited in northern Kerala (Freeman 2003: 462), and the $16^{\text {th }}$ century Adhyātma Rāmāyanam, whose author Eluttacchan declared Malayalam the equal of Sanskrit, and his composition equal to the Veda. ${ }^{19}$ The cultural media via which such works have been transmitted and encountered are predominantly performative (ibid.: 438).

North Indian sacred literature in vernacular languages has also been primarily orally composed and performed and, as in South India, many important early works (in e.g. Assamese, Oriya and Bengali) are translations or retellings of Sanskrit texts. These include Jñanndev's creative commentary in Marathi on the Bhagavadgìt $\bar{a}$, the Bhāvārthadīpikā or Jñaneśvarī (13 ${ }^{\text {th }}$ century), in which the author vows to place Marathi and Sanskrit on the same royal throne. A passage at the end of this work has become a popular prayer among Marathi speakers, and the work as a whole occupies a place in Marathi culture which is normally reserved for sacred works in Sanskrit. North Indian vernacular literature commonly transcends traditional social hierarchies, and several low-caste and female authors enjoy a prominent status, with their texts

\footnotetext{
${ }^{19}$ Kampan's $12^{\text {th }}$ century retelling of the Rāmāyana in Tamil, the Irāmāuatāram, the verses of which are inscribed on temple walls across central and southern Tamil Nadu, predates both of these.
} 
recited as part of the liturgy in temples. Many works claim that their raison d'être is to make available sacred works in Sanskrit to the local populace, though several of these have far transcended such secondary status. Perhaps the best example here is the Rāmcaritmānas ("Lake of Rāma's Deeds"), a $16^{\text {th }}$ century retelling of the story of Rāma composed by Tulsīdās in the eastern Hindi dialect of Avadhi. The Rāmcaritmānas is experienced by most of its audience in oral or musical performance, being ritually recited (despite the fact that few modern Hindi speakers understand its archaic language) or acted out at popular festivals across northern India. However, it has also achieved widespread eminence as a written text, whether inscribed on temple walls, as an object of temple worship, or in the scores of printed editions found thoughout the subcontinent. For the majority of Hindus in North India, it remains the most popular narrative account of the life and career of Rāma, more popular than the Rāmāyana itself, and it has been described by several Western observers as "the Bible of Northern India" (Lutgendorf 1991: 1).

\section{References}

Brick, D. (2006) "Transforming Tradition into Texts: The Early Development of Smrti”, Journal of Indian Philosophy 34: 287-302.

Freeman, Rich (2003) "Genre and Society. The Literary Culture of Premodern Kerala", in Sheldon Pollock (ed.) Literary Cultures in History. Reconstructions from South Asia, Berkeley, Los Angeles, London: University of California Press, 437-500.

Goldman, Robert and Goldman, Sally Sutherland (2010) "Rāmāyaṇa", in Knut A. Jacobsen et al. (eds.) Brill's Encyclopedia of Hinduism. Volume Two, Boston, Leiden: Brill, 111-126.

Jamison, Stephanie W. and Brereton, Joel P. (trans.) (forthcoming) The Rigveda, Oxford: Oxford University Press.

Lutgendorf, Philip (1991) The Life of a Text: Performing the Rāmcaritmānas of Tulsīdās, Berkeley, Los Angeles, London: University of California Press.

Malinar, Angelika (2007) The Bhagavadgìtā: Doctrines and Contexts, Cambridge: Cambridge University Press.

McCrea, Lawrence (2011) "Mīmāṃsā", in Knut A. Jacobsen et al. (eds.) Brill's Encyclopedia of Hinduism. Volume Three, Leiden, Boston: Brill, 643-656.

Narayana Rao, Velcheru (2004) "Purāna", in Sushil Mittal and Gene Thursby (eds.) The Hindu World, New York, NY: Routledge, 97-118.

Olivelle, Patrick (trans.) (2004) The Law Code of Manu, Oxford: Oxford University Press.

Olivelle, Patrick (2010) "Dharmaśāstra: a textual history", in Timothy Lubin, Donald R. Davis Jr., and Jayanth K. Krishnan (eds.) Hinduism and Law: An Introduction, New York: Cambridge University Press, 28-57.

Pollock, Sheldon (1997) “The 'Revelation' of 'Tradition': Śruti, Smrti, and the Sanskrit Discourse of Power", in S. Lienhard and I. Piovano (eds.) Lex et Litterae: Studies in Honour of Professor Oscar Botto, Alessandria: Edizioni dell'Orzo, 395417. 
Pollock, Sheldon (2006) The Language of the Gods in the World of Men. Sanskrit, Culture, and Power in Premodern India, Berkeley, Los Angeles, London: University of California Press.

Ramanujan, A. K. (trans.) (1973) Speaking of Śiva, London: Penguin Books.

Smith, Frederick M. (1994) "Purāṇaveda", in Laurie L. Patton (ed.) Authority, Anxiety and Canon: Essays in Vedic Interpretation, Albany: SUNY Press, 97-138.

Watts, James W. (2006) "The Three Dimensions of Scriptures", Postscripts 2.2-3: 135-159.

Witzel, Michael (1997) "The Development of the Vedic Canon and its Schools: The Social and Political Milieu", in Witzel (ed.): Inside the Texts, Beyond the Texts. New Approaches to the Study of the Vedas, Cambridge: Harvard Oriental Series, 257-345. 